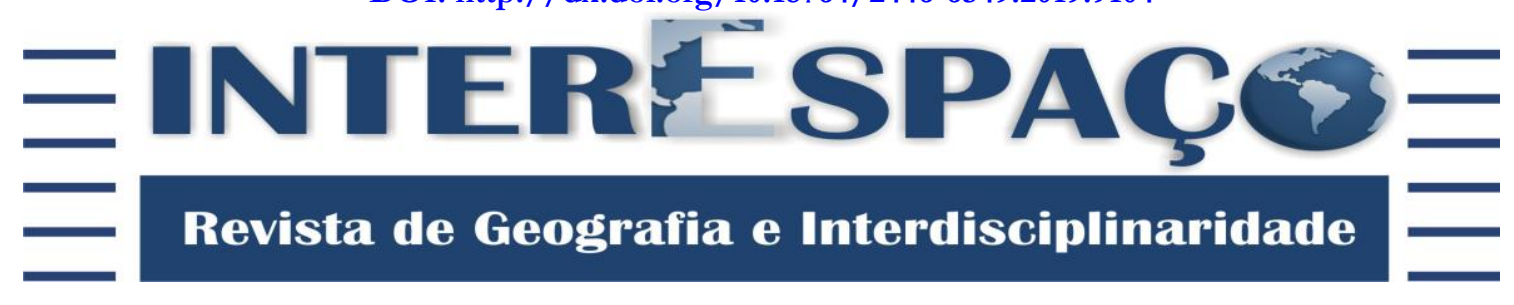

\title{
VERTICALIZAÇÃO URBANA DE TERESINA-PI: considerações a respeito da produção do espaço a partir da construção vertical
}

\section{URBAN VERTICALIZATION OF TERESINA-PI: considerations regarding the production of the space from the vertical construction}

VERTICALIZACIÓN URBANA DE TERESINA-PI: consideraciones a respeto de la producción del espacio a partir de la construcción vertical

\section{Sara Raquel Cardoso Teixeira de Sousa}

Mestra em Geografia pela Universidade Federal do Piauí - UFPI. Docente Substituta no Centro de Ensino Superior de Caxias da Universidade Estadual do Maranhão - CESC/UEMA. sousasrct@gmail.com

\section{Bartira Araújo da Silva Viana}

Doutora em Geografia pela Universidade Federal de Minas Gerais - UFMG. Professora Adjunta III do Curso de Geografia e do Programa de Pós-graduação em Geografia da Universidade Federal do Piauí - UFPI.

bartira.araujo@ufpi.edu.br

Recebido para avaliação em 08/06/2018; Aceito para publicação em 10/12/2018.

\section{RESUMO}

O presente artigo traz informações a respeito da verticalização urbana da cidade de Teresina-PI e considerações sobre a produção do espaço. O objetivo principal foi analisar a construção dos empreendimentos verticais e a produção do espaço urbano a partir desse tipo de construção, destacando como a mesma se espacializou no decorrer da evolução histórica da cidade de TeresinaPI. Esta pesquisa apresenta algumas considerações importantes a respeito da verticalização e da discussão teórica que envolve a temática, podendo contribuir para pesquisas futuras que visam apreciar a evolução histórica da verticalização na cidade de Teresina, tanto para profissionais da Geografia como também da História e Arquitetura.

Palavras-chave: Verticalização; Espaço Urbano; Teresina-PI.

\section{ABSTRACT}

This article presents information about the urban verticalization of the city of Teresina-PI and considerations about space production. The main objective is to analyze the construction of vertical enterprises and the production of urban space from this type of construction, highlighting how it has been spatialized in the course of the historical evolution of the city of Teresina-PI. This research presents some important considerations regarding the verticalization and the theoretical discussion that surrounds the theme, being able to contribute to future researches that aim to appreciate the historical evolution of the verticalization in the city of Teresina, for professionals of Geography as well as History and Architecture.

Keywords: Verticalization; Urban Space; Teresina-PI.

\section{RESUMEN}

El presente artículo trae informaciones sobre la verticalización urbana de la ciudad de Teresina-PI y consideraciones sobre la producción del espacio. El objetivo principal es analizar la construcción de 
| Verticalização urbana de Teresina-PI: considerações a respeito da produção do espaço a partir da construção vertical|

| Sara Raquel Cardoso Teixeira de Sousa | Bartira Araújo da Silva Viana |

los emprendimientos verticales y la producción del espacio urbano a partir de ese tipo de construcción, destacando cómo la misma se espacializó en el transcurso de la evolución histórica de la ciudad de Teresina-PI. Esta investigación presenta algunas consideraciones importantes acerca de la verticalización y de la discusión teórica que envuelve la temática, pudiendo contribuir a investigaciones futuras que apuntan a apreciar la evolución histórica de la verticalización en la ciudad de Teresina, tanto para profesionales de la Geografía como también de la Historia y la Arquitectura.

Palabras clave: Verticalización; Espacio Urbano; Teresina-PI.

\section{INTRODUÇÃO}

As mudanças ocorridas no modo de produção e a evolução técnica dos últimos dois séculos refletiram, de forma significativa, na organização do espaço urbano. Nesse sentido a Geografia Urbana traz, através de seus estudos, o apoio necessário para o entendimento das dinâmicas que ocorrem na cidade e no seu entorno.

Desta forma, o planejamento e execução de projetos urbanísticos como fruto da produção e reprodução do espaço com as mais diversas funções, sejam estas comerciais ou residenciais, são temas tratados pela Geografia Urbana, a exemplo de discussões relacionadas à verticalização e sua relevância no contexto da cidade de Teresina - Piauí. Cumpre destacar que as transformações presentes na paisagem urbana fazem parte da nova lógica de produção do espaço urbano e da atuação de diversos agentes.

Essas modificações têm contribuído para a dinâmica na produção espacial da Cidade, assim como para a reestruturação urbana no âmbito da produção residencial. Estudos, como os realizados por Corrêa (1989), apontam que esse processo, são consequências da ação dos promotores imobiliários e do Estado. Os agentes reprodutores e produtores do espaço determinam a valorização e desvalorização de locais nas cidades, sendo que os agentes imobiliários são estimulados a investir em padrões arquitetônicos e urbanísticos que supervalorizam o metro quadrado em determinadas áreas urbanas.

Apesar de urbanizar-se tardiamente, comparado com outras cidades brasileiras, Teresina demonstrou, ao longo de sua história recente, um padrão de verticalização que acompanha as mudanças econômicas ocorridas no país. Por volta de 1970 surgem edificações verticais comerciais no centro de Teresina. A produção de empreendimentos verticais residenciais se intensifica na década de 1980 e se consolida na década de 1990 nas regiões Centro-Norte e Leste da capital piauiense devido a investimento em infraestrutura e serviços, agregando valor inicialmente às áreas de alguns bairros, como Cabral e Ilhotas (região Centro-Norte), Jóquei e Fátima (região Leste) e ainda a Avenida Frei Serafim (Centro). Nos anos 2000, a região Leste continuou sendo a mais atrativa para construção 
| Verticalização urbana de Teresina-PI: considerações a respeito da produção do espaço a partir da construção vertical|

| Sara Raquel Cardoso Teixeira de Sousa | Bartira Araújo da Silva Viana |

de empreendimentos verticais, refletindo o grande dinamismo do setor imobiliário e o papel do Estado como responsáveis pela (re)estruturação do espaço urbano.

Nesse sentido, houve a necessidade, por parte do Estado, de estabelecer normas que alcançassem também as construções verticais e sua espacialização dentro do município de Teresina, influenciando no número de pavimento das mesmas em determinadas áreas.

Assim, surgiram questionamentos a respeito da verticalização de Teresina. Como se deu essa verticalização desde seu surgimento na referida cidade em 1970 e como se comporta nos dias atuais? Quais as principais leis que normatizam esse tipo de construção em Teresina? Essas leis são respeitadas? Existem formas de construir prédios com andares superiores ao permitido em determinadas zonas da cidade de Teresina?

A presente pesquisa traz informações sobre a verticalização da cidade de Teresina tal como a normatização que rege a construção desse tipo de empreendimento. O objetivo Geral foi analisar a construção dos empreendimentos verticais e a produção do espaço urbano a partir desse tipo de construção e como a mesma se espacializou dentro da evolução histórica da cidade de Teresina-PI.

\section{GEOGRAFIA URBANA: espaço urbano e verticalização}

A ciência geográfica fornece suporte para diversas discussões e pesquisas que envolvem o ambiente urbano, seja no que diz respeito aos aspectos físicos, como também naquelas que envolvem o desenvolvimento e a expansão das cidades, levando em consideração o aspecto comportamental, organizacional e social. Nesse sentido, quando se trata de estudos que envolvem a cidade, torna-se necessário compreender alguns fenômenos, como o processo de urbanização e as tendências de expansão dos espaços urbanos.

A cidade, para a Ciência Geográfica, é produto de diversos acontecimentos econômicos, sociais, antrópicos complexos e interligados, possibilitando analisar o urbano pelas demais óticas metodológicas geográficas. Conforme Silva (1997, p. 85):

Conhecer a cidade é desvendá-la, penetrar em seus labirintos, perder-se no meio
do burburinho de sua multidão anônima aguça a curiosidade de vários
profissionais. A cidade parece resistir à análise e insiste em ser o espaço da
aglomeração, do coletivo e, também do individual. Gente na cidade é povo, é
massa. Povo na cidade às vezes sussurra; às vezes urra - define e defende
posições, demarca territórios, delimita fronteiras.

Esse autor expressa ainda necessidade de conhecer a cidade e tudo o que está envolvido nela, visto que o espaço urbano é um universo dentro da mesma, representando 
| Verticalização urbana de Teresina-PI: considerações a respeito da produção do espaço a partir da construção vertical|

| Sara Raquel Cardoso Teixeira de Sousa | Bartira Araújo da Silva Viana |

tudo o que acontece de complexo e diferente. Assim, ainda no que se refere à ela, Affonso (2002, p. 71) afirma que "a cidade atrai o homem por ser lugar de acontecimentos, de negócios, de encontros, onde decisões que determinam o futuro e a vida de todos os homens são tomadas [...]”. Dessa forma, a afirmação do autor permite observar que os estudos da cidade envolvem diversos aspectos em torno do homem.

Souza (2008) afirma que cidade é tão complexa que a sua definição fica difícil de ser descrita. A respeito desse conceito, o autor faz algumas considerações ao destacar que, "considerando o uso do solo ou das atividades econômicas que caracterizam sua ocupação, pode-se definir a cidade como um espaço de produção não agrícola, que não se caracteriza pelas atividades econômicas primárias" (SOUZA, 2008, p.27).

Dessa forma, o autor afirma que é possível encontrar atividades primárias na cidade na faixa de transição do urbano para o rural (franja urbana).

Além disso, o autor acima citado, ao tratar da questão da franja urbana, explica que esta, somente por possuir aspecto visual relacionado ao rural, não pode ser definida como área rural uma vez que a cidade pode ser considerada como um "centro de gestão do território" (SOUZA, 2008, p.31), pois se caracteriza também por abrigar diversas empresas que desempenham papel importante na produção do espaço, como questões culturais e de poder, este último sendo representado pelo Estado.

Conforme Souza (2008, p. 31), outra característica que deve ser levada em consideração para caracterizar a cidade relaciona-se à quantidade de habitantes que nela residem. No entanto, o autor enfatiza o fato de que cidades grandes podem não ser tão interessantes do ponto de vista da pesquisa. Por mais complexa que seja a definição, sabese que estas possuem função e influenciam, nas diversas escalas, os aspectos políticos, culturais, econômicos e sociais.

O processo de urbanização é, segundo Santos (2008), fruto dos acontecimentos históricos, políticos e econômicos, sendo que a cidade tornou-se local de especulação do uso da terra. O autor explica ainda que o "Meio Geográfico Artificial", advindo da Revolução Industrial, se torna cada vez mais instrumentalizado, agregando valor à terra urbana.

Assim, o espaço urbano está contido na cidade, porém, ele é tão complexo e grandioso que metaforicamente pode-se afirmar que é um universo de ações, informações e relações que ocorrem no espaço da cidade.

Corrêa (1989) considera o espaço urbano como um conjunto de diferentes usos da terra justapostos entre si, sendo ao mesmo tempo fragmentado e articulado. $\mathrm{O}$ autor ainda afirma que o espaço urbano reflete a sociedade e possui agentes produtores, sendo eles: 
| Verticalização urbana de Teresina-PI: considerações a respeito da produção do espaço a partir da construção vertical|

| Sara Raquel Cardoso Teixeira de Sousa | Bartira Araújo da Silva Viana |

proprietários dos meios de produção; proprietários fundiários; promotores imobiliários; os grupos sociais excluídos e o Estado. Esse autor discorre também que os agentes produtores do espaço são complexos e produzem e reproduzem o espaço urbano.

\section{AGENTES PRODUTORES E REPRODUTORES DO ESPAÇO URBANO}

De acordo com Roberto Lobato Corrêa (1989), há uma definição de quem são e quais são as ações e as consequências dessa atuação dos agentes produtores no espaço urbano. Assim, os proprietários dos meios de produção são os proprietários industriais e das grandes empresas comerciais, sendo estes grandes consumidores do espaço que necessitam de terrenos a baixo custo e em locais que favoreçam seus empreendimentos. Conforme afirma Carlos (2011, p. 70),

\footnotetext{
A noção de produção de espaço, como vimos, recai sobre conteúdos e determinações e nos obriga a considerar os vários níveis a realidade enquanto momento diferenciados da reprodução geral da sociedade em sua complexidade. Focalizando na sociedade como sujeito da ação consciente, o Estado como aquele da dominação política, o capital em suas estratégias objetivando sua reprodução continuada (e aqui nos referimos às frações do capital, que são o industrial, o comercial e o financeiro e suas articulações com os demais setores da economia, tais como o mercado imobiliários) e, por fim, os sujeitos sociais que, em suas necessidades/desejos vinculados à realização da vida humana, têm o espaço como condição, meio e produção de sua ação [...] (grifos do autor).
}

A autora demonstra que os conflitos são constantes no espaço urbano. Além disso, Carlos (2011) defende que esses conflitos, observados em torno dos agentes de produção do espaço, explicam as estratégias dos mesmos, uma vez que a parcela do solo é fragmentada e valorizada, compondo o circuito das mercadorias, ou seja, é comerciável. Outrossim, estes agentes produtores tendem a atrair capital com o uso destas parcelas de solo.

No que diz respeito aos proprietários imobiliários, segundo Corrêa (1989), estes, enquanto agentes produtores do espaço urbano, especulam o máximo suas terras com a finalidade de obter lucro. Realizando acordos com o Estado no sentido de interferir nas leis de uso e ocupação de solo.

Os proprietários imobiliários e o Estado são os agentes que causam impactos no espaço urbano com relevante significância, podendo ser considerados como os dois maiores responsáveis pela segregação espacial e pela supervalorização de algumas áreas construídas. Quanto maior for o poder aquisitivo dos proprietários imobiliários, maior será a sua influência sobre o Estado. 
| Verticalização urbana de Teresina-PI: considerações a respeito da produção do espaço a partir da construção vertical|

| Sara Raquel Cardoso Teixeira de Sousa | Bartira Araújo da Silva Viana |

Ainda a respeito desse agente, observa-se sua influência na zona urbana. Nas cidades, eles atuam como proprietários de terra, especialmente nas zonas periféricas, atraindo investimentos em infraestrutura através do Estado. Também se observa estas práticas em terrenos supervalorizados.

Assim, os promotores imobiliários possuem o poder de segregar o espaço juntamente com o Estado, pois tem o poder de direcionar a população menos favorecida para as áreas periféricas da cidade. Esta situação decorre do fato dos mesmos agregarem alto valor a terra, impossibilitando pessoas com baixo poder aquisitivo de comprá-la, e assim, suas ações expressam conflitos de interesse. Ainda conforme Corrêa (1989), o Estado oferece o apoio a este agente nessas ações, contribuindo para que ocorra esse tipo de exclusão.

É possível observar áreas onde existe a concentração da população pobre, conforme os aspectos sócio-espaciais, independente se o bairro é próximo da área central da cidade ou periférico, caracterizando o processo segregatório. Segundo Gottschalg (2012, p. 7):

\footnotetext{
No que se refere aos aspectos sócio-espaciais, manifestam-se na ocupação de áreas impróprias e inadequadas à moradia - as denominadas favelas, Assentamentos Precários ou Aglomerados Subnormais Assentamentos localizados nas periferias, distantes dos centros urbanos; ou mesmo localizadas em zonas centrais, próximos a bairros valorizados pelo mercado imobiliário, mas em áreas de topologia imprópria à construção, em situações de risco geológico.
}

Assim, áreas verticalizadas também são palco de segregação espacial, independente da classe social dominante na área, uma vez que diversos fatores contribuem e agem de forma mais relevante para que a segregação ocorra de modo mais significativo.

\section{SEGREGAÇÃO ESPACIAL E A VERTICALIZAÇÃO}

Em primeiro plano, o conceito de verticalização foi apresentado sob a perspectiva da Engenharia, Arquitetura e Geografia. Para Oliveira et al. (2015, p. 12):

A construção de edifícios constitui-se num fenômeno chamado verticalização urbana. Causadora de mudanças na paisagem e nas relações sociais e econômicas de uma cidade, a verticalização tem vantagens e desvantagens apontadas e estudadas por diversos especialistas.

Rodrigues (2016, p. 6) afirma que "verticalização, entende-se a construção de edifícios com diversos pavimentos, possibilitando a criação de solo urbano, já que, numa 
| Verticalização urbana de Teresina-PI: considerações a respeito da produção do espaço a partir da construção vertical|

| Sara Raquel Cardoso Teixeira de Sousa | Bartira Araújo da Silva Viana |

mesma área do terreno, a sobreposição de pavimentos permite a multiplicação das unidades construídas". A autora explica que se pode considerar uma construção vertical aquela que possui mais de dois pavimentos, porém, deve-se destacar que outros autores consideram como empreendimento vertical, aquele construído a partir de três e até quatro pavimentos.

Além disso, a referida autora discorre ainda que o Estado e o setor imobiliário contribuem para segregar parte da população menos favorecida e direcioná-la para áreas periféricas. Em sua obra, Freitas (2005) analisou as cidades de Recife e Olinda considerando as áreas verticais e horizontais do ponto de vista arquitetônico e geográfico. No entanto, sua análise predominante visa às questões da arquitetura chamando atenção para o uso de obras que tratam as temáticas da Geografia Urbana.

Para Souza (1994), a verticalização trata de locais com concentração de prédios com mais de um pavimento. Porém, Sposito (1991) discorre que esta é caracterizada pela “[...] produção imobiliária de 4 pavimentos [...]”. Nessa perspectiva, o estudo analisará a produção imobiliária da verticalização realizada em Teresina a partir de quatro pavimentos.

Quanto à segregação promovida pela verticalização, Oliveira et al. (2015) afirmam que as construções verticais, diferentemente das construções horizontais, agregam valor ao imóvel e ao espaço no qual o empreendimento foi construído. Nesse quesito, também se deve destacar que os serviços são atraídos para as áreas verticalizadas, por se configurarem como áreas compactadas. Para Corrêa (2013, p. 39), a segregação residencial “[...] é um dos mais expressivos processos espaciais que geram fragmentação do espaço [...]". Freitas (2015) afirma que estas áreas, além se terem o $\mathrm{m}^{2}$ mais caro, também atraem serviços de alto padrão.

Ainda segundo esse autor, as áreas verticalizadas são, em geral, dotadas de infraestrutura que permite o bom funcionamento da circulação de pessoas, além da oferta de serviços. Freitas (2015) afirma que a faixa de preço dos imóveis verticalizados por si só já seleciona o status econômico das pessoas que residem o local. Além disso, deve-se destacar que, apesar do foco não ser especificamente a segregação espacial promovida pela verticalização, Freitas (2015) mostra-se uma fonte bibliográfica indispensável para a discussão, uma vez que o trabalho realizado pelo autor está inserido na perspectiva da região Nordeste.

HISTÓRICO DA CIDADE DE TERESINA: pequeno ensaio sobre o surgimento e a urbanização 
| Verticalização urbana de Teresina-PI: considerações a respeito da produção do espaço a partir da construção vertical|

| Sara Raquel Cardoso Teixeira de Sousa | Bartira Araújo da Silva Viana |

Teresina é a única capital nordestina que não está localizada na faixa litorânea. Capital do Piauí desde 1852, após transferência da antiga capital, Oeiras, na região do rio Canindé, para as margens do médio Parnaíba na "Chapada do Corisco". Essa mudança ocorreu com a finalidade de melhorar as articulações comerciais do estado (SILVA, 1952).

Deve-se enfatizar que é uma cidade cujo processo de urbanização é considerado recente se comparada com as principais capitais brasileiras.

Levando em consideração as datas das publicações, Abreu (1983), no referido estudo, descreveu a cidade de Teresina até a década de 1980, enquanto Façanha (1998) publicou seu estudo no final da década de 1990. Dessa forma, tornou-se necessário estudar outros autores que pesquisam a temática da evolução urbana de Teresina até o ano de 2017, recorte temporal utilizado na pesquisa. Ainda no que tange ao surgimento da cidade de Teresina, Silva (2012, p. 218) explica que foi a primeira capital planejada e edificada ainda no regime imperial.

De acordo com Teresina (2016), a instalação do primeiro núcleo urbano da atual Teresina aconteceu em 1832 na Vila do Poti, onde na atualidade corresponde ao bairro Poti Velho, localizado na região Centro-Norte. Apenas em 1855, a Vila do Poti foi elevada a categoria de cidade, ano correspondente à mudança da capital.

Teresina é a única capital nordestina que está localizada no interior do continente e teve suas primeiras construções organizadas em torno da Vila do Poti, às margens do rio Poti, logo após a transferência da capital de Oeiras para Teresina. De acordo com Abreu (1983, p. 14), a transferência teve como um dos fatores de incentivo à sua posição geográfica, pois havia a necessidade de melhor interação com os demais Estados, além de colocar a capital do Piaú em um ponto estratégico econômica e administrativamente, visando permitir articulações com cidades localizadas no meio-norte brasileiro, em especial a economia pecuária, destaque naquele período.

Assim, uma cidade inicialmente planejada, onde, de acordo com Viana (2003, p. 2), possui um traçado geométrico com a forma de tabuleiro de xadrez, tem como centro a Igreja Nossa Senhora do Amparo (primeira edificação da cidade), cujo planejamento foi idealizado pelo então Conselheiro Saraiva. Segundo Silva (2012), este traçado sofreu forte influência do modelo urbano Português do século XVIII, embora a construção de Teresina tenha ocorrido no século XIX. Em 28 de abril de 1852, foi enviado ao presidente da Província do Piauí, o desenho do plano da cidade de Teresina.

Como é possível observar no Plano urbanístico de Teresina datado de 1855, este se assemelha aos modelos urbanos portugueses principalmente em seu aspecto retilíneo, dentre outros aspectos destacados por Silva (2012, p. 218): 
| Sara Raquel Cardoso Teixeira de Sousa | Bartira Araújo da Silva Viana |

\begin{abstract}
O modelo urbano português se caracteriza por apresentar linhas retilíneas, regularidade de volume, rigidez geométrica e concentração dos poderes estabelecidos - governo, justiça - no entorno da praça principal. Diferentemente de Lisboa, um terceiro poder se estabeleceu na praça principal em Teresina: a religião, que assumiu importante papel na ocupação da cidade e esteve relacionada à implantação da igreja matriz na Praça Deodoro da Fonseca. Tais características indicam um padrão espacial com dimensionamento de traçado e agrupamento tipológico que podem ser observados na forma e métrica das praças centrais das cidades coloniais brasileiras. Esses mesmos princípios também estão presentes no plano de Teresina, indicando a influência do modelo português. $O$ fato de ser repetido um século depois apenas confirma a aplicabilidade dos princípios urbanísticos da escola portuguesa.
\end{abstract}

Silva (2012, p. 226) ressalta ainda que o plano métrico proposto por Saraiva traçava o desenho da cidade a partir da perspectiva da Praça Deodoro. Assim, o lado maior possuía três módulos e o lado menor apenas dois, o que diferencia a cidade de Teresina das outras cidades construídas na época baseadas nos moldes de Portugal, pois as demais cidades eram construídas a partir de um prédio principal (Palácio), enquanto na planta proposta para Teresina se expandiu a partir de uma praça.

Por volta dos anos de 1940, conforme afirma Façanha (1998, p. 27), outra cidade do território piauiense ganhou destaque, Parnaíba, em face de posição geográfica e suas articulações comerciais, que a colocou no cenário regional e internacional devido ao extrativismo. Porém, essa cidade também perde força comercial com o declínio das exportações destes produtos primários.

Ainda de acordo com Viana (2003), por volta dos anos de 1960 houve uma intensa expansão para as regiões Leste e Centro-Norte, assim como no sentido sul. Esta decorreu, dentre outros fatores, devido a criação de duas avenidas consideradas as vias de acesso mais importantes para a região sul (Miguel Rosa e Barão de Gurgueia). Deve-se enfatizar também que a expansão de Teresina para a região Sul decorreu de aspectos físicos, como o aplainamento do terreno.

Neste contexto destaca-se ainda a construção de conjuntos habitacionais importantes entre os anos de 1969 e 1980. Conforme afirma Façanha (1998, p. 37), o conjunto habitacional Parque Piauí, construído em 1969, refletia as tendências do regime político Pós-64 e expressava a segregação habitacional, além de confirmar o expressivo crescimento de moradias que eram construídas na zona Sul.

No tocante aos anos de 1970, Teresina permanecia se destacando como a cidade mais influente do Estado, havendo a tendência de desenvolvimento do setor econômico de serviços, sendo este fato evidenciado com mais expressividade a partir da presente data.

Segundo Façanha (2003, p. 3), ainda na década de 1970 é possível observar o processo de descentralização espacial do centro e a concentração de comércios nos bairros, 
| Verticalização urbana de Teresina-PI: considerações a respeito da produção do espaço a partir da construção vertical|

| Sara Raquel Cardoso Teixeira de Sousa | Bartira Araújo da Silva Viana |

permitindo aos moradores consumir sem, necessariamente, ter a obrigatoriedade de se deslocar para o centro da cidade, sendo que outros bairros também ganham destaque neste mesmo contexto.

$\mathrm{Na}$ década de 1990, a capital piauiense cresceu significativamente, como aponta Viana (2003, p. 57), ao explicar que o número de habitantes aumentou e o processo de urbanização se mostrou consolidado. Façanha (2012, p. 7) destaca que o setor do comércio também se consolidou, sendo considerado o principal setor econômico da capital. Cumpre destacar, ainda neste período, o surgimento de novas vilas e bairros, além da implementação de leis municipais importantes sobre o uso e ocupação do solo urbano. Conforme Façanha (2012, p. 7-8):

\begin{abstract}
Em 1992, o governo municipal publica uma nova legislação urbana. Esse documento, através das Leis de $\mathrm{n}^{\circ}$ 2.264, 2.265 e 2.266, de 16 de dezembro, definiu a ocupação do solo urbano, o uso do solo urbano e o código de obras e edificações de Teresina. No texto de apresentação do documento, o Prefeito Wall Ferraz naquele contexto, justificou a necessidade de atualização da legislação, ao dizer que percebia, "por toda parte, o crescimento vertical da cidade. A população aumentando a olhos vistos. O crescimento expandindo-se pelos bairros. Construções realizadas de forma desordenada. Tudo, portanto, a reclamar modernas e eficazes leis municipais" (Legislação Urbana de Teresina, 1993, p. 1). Essa legislação surgiu por pressão dos agentes do setor imobiliário, sinal importante da ampliação do nível de organização desse setor, além de consolidar nos primeiros anos de 1990 o processo de verticalização em Teresina.
\end{abstract}

Conforme expressa o autor, estas leis refletem a intervenção do poder público. Segundo Viana (2003) e Façanha (2012), foram nos anos 1990 que o processo de verticalização em Teresina, além de se tornar intenso, passou a expressar a especulação imobiliária e a ocupação de áreas já valorizadas por pessoas de alto pode aquisitivo.

Ainda Segundo Façanha (1998, p. 43), "ao final da primeira metade da década de 90, o município de Teresina ocupava uma área de $1.809 \mathrm{Km}$, tendo a sua zona urbana ampliada, nos últimos anos, para 176,32 Km e a área rural reduzida para 1.632,60 Km”.

Assim, cada superintendência ficou responsável por gerir uma região administrativa com a finalidade de solucionar problemas de forma eficaz e mais rápida. Para isso, foram reunidos documentos a respeito de cada bairro e expostos para consulta popular através do site da Prefeitura Municipal de Teresina, contendo informações sobre cada bairro de cada região administrativa, desde o histórico até dados censitários.

Os anos de 2000 foram marcados também por muita modernidade e evolução da cidade de Teresina a partir da atuação do poder público municipal, que trabalhou no sentido de organizar melhor a cidade e repensar, a partir de ações que promovessem melhorias no bem-estar da população. 
| Verticalização urbana de Teresina-PI: considerações a respeito da produção do espaço a partir da construção vertical|

| Sara Raquel Cardoso Teixeira de Sousa | Bartira Araújo da Silva Viana |

Segundo Viana (2007, p. 47), as propostas da prefeitura foram baseadas na Agenda 21, estabelecendo a necessidade de promover e repensar no desenvolvimento das cidades de forma sustentável a fim de promover o mínimo de interferências ao meio ambiente.

\section{A VERTICALIZAÇÃO DE TERESINA NO CONTEXTO HISTÓRICO}

O processo de verticalização de Teresina acompanhou o processo de urbanização tardio, em virtude do contexto da colonização brasileira e piauiense. Também se desenvolveu a partir de influências internas e externas em especial, da migração de grandes contingentes de habitantes, assim como pelo desenvolvimento econômico da capital do Piauí.

Tal como nos outros estados brasileiros, a verticalização expressa uma segregação social, principalmente nos bairros com maior concentração de construções verticais. A especulação imobiliária também é um fator determinante para grande concentração de prédios de médio e alto padrão em alguns bairros específicos da cidade, em especial aqueles localizados na região Leste (Figura 1).

Figura 1 - Mapa de localização dos empreendimentos verticais em Teresina-PI. 1971-2017.

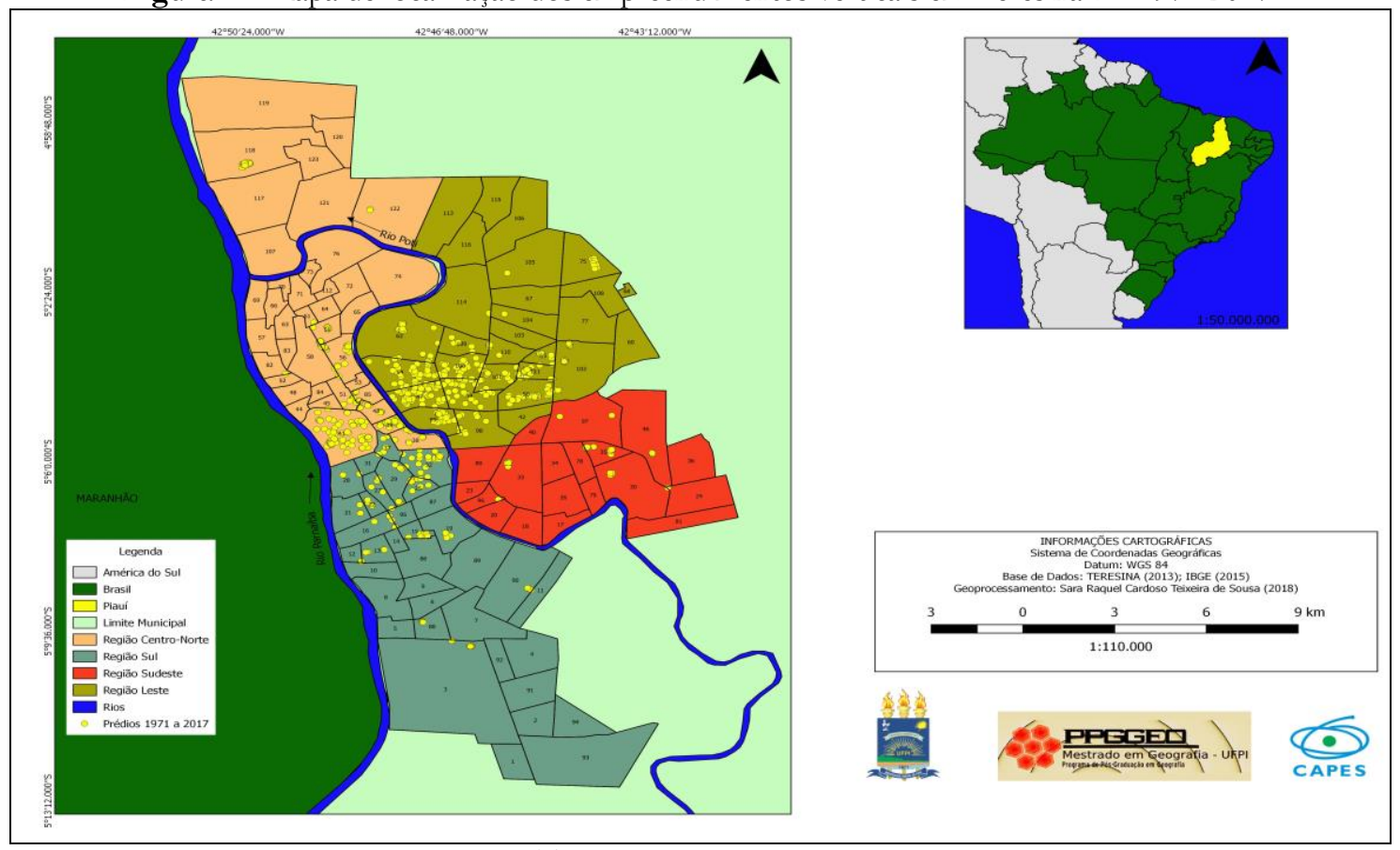

Base de dados: IBGE (2015); TERESINA (2016). Organização e Geoprocessamento: Sara Raquel C. T. de Sousa (2018).

Para que haja uma melhor compreensão sobre a espacialização da verticalização de Teresina, será traçado um histórico baseado nos principais autores piauienses, pois estes estudos tornam-se de fundamental importância para o presente trabalho. 
| Verticalização urbana de Teresina-PI: considerações a respeito da produção do espaço a partir da construção vertical|

| Sara Raquel Cardoso Teixeira de Sousa | Bartira Araújo da Silva Viana |

A escolha específica de alguns autores se deu pelo número da produção literária com a mesma temática, tal como o número de citações destes autores em outros textos. Desse modo, foram destacados Viana (2003) e Façanha (1998; 2003), por construírem trabalhos específicos na área e pela sua representatividade no contexto enunciado.

No contexto do crescimento vertical de Teresina, deve-se destacar que uma das primeiras construções com mais de um pavimento, que viria posteriormente a ser símbolo histórico da cidade, que teve a conclusão de sua construção datada de 1905, foi o Colégio Sagrado Coração de Jesus, também conhecido como Colégio das Irmãs. Este prédio é considerado uma das primeiras construções verticais localizadas em uma das avenidas mais importantes de Teresina no contexto histórico da capital, a Frei Serafim.

Segundo Viana (2003, p. 65), entre os anos de 1960 e 1970, é possível observar na área central da cidade de Teresina, as primeiras construções verticais, porém estas não se configuravam ainda em número significativo para ser definido como área verticalizada.

Cumpre enfatizar também, como determinante para o início da aceleração da verticalização e modernização de Teresina, as obras realizadas no governo do Estado do Piauí, no período de 1970 a 1975. Elas influenciariam de maneira significativa também a expansão da área urbana, uma vez quem permitiram melhorias de acesso às áreas periféricas da cidade. Segundo Costa (2014, S.p), as obras construídas no governo de Alberto Silva eram volumétricas e tiveram grande importância no cenário da cidade de Teresina, principalmente interferindo nas questões urbanas. Segundo este autor:

Foi durante os primeiros anos da década de 1970, que o governo de Alberto
Silva construiu as grandes obras na capital piauiense, tais como o estádio de
futebol Albertão, o Tribunal de Justiça do Estado do Piauí, a Companhia
Energética do Piauí - Cepisa, o asfaltamento das Avenidas Miguel Rosa e Frei
Serafim, o Hospital de Doenças Infecto Contagiosas - HDIC, que atualmente
denomina-se Hospital de Doenças Tropicais Natan Portela, a Universidade
Federal do Piauí e o Hotel Piauí, entre outras (COSTA, 2014, s.p).

No que se refere à década de 1980, observou-se um aumento no número de indústrias em Teresina, levando-a uma mudança na dinâmica da cidade em virtude do desenvolvimento deste setor econômico, uma vez que também houve a expansão de forma expressiva da construção civil. Conforme Façanha (2003, p. 5-6), na década de 1980 surgiram 56 imobiliárias, contribuindo, assim, para o processo de verticalização que se intensificou, possível de ser observado no centro da cidade, nos bairros Cabral, avenida Frei Serafim e Ilhotas (região Centro-Norte). Deve-se destacar ainda que a maioria dos edifícios localizados na região Centro-Norte era destinada a fins comerciais. 
| Verticalização urbana de Teresina-PI: considerações a respeito da produção do espaço a partir da construção vertical|

|Sara Raquel Cardoso Teixeira de Sousa | Bartira Araújo da Silva Viana |

No que diz respeito à década de 1990, observa-se um período no qual as construções verticais ocorrem com maior vigor e expressividade. De acordo com Viana (2003, p. 68), é possível observar a segregação decorrente da verticalização, em especial nas zonas Centro e Leste da cidade. Os bairros que se destacam neste contexto, conforme afirma Viana (2003, p. 69), foram Jóquei, Fátima, Cabral, Ilhotas e avenida Frei Serafim.

No que compete aos anos de 2000 até a atualidade, diversos trabalhos foram elaborados com o intuito de analisar áreas verticalizadas específicas da cidade de Teresina. Diversos textos dissertativos foram produzidos com a mesma temática, contribuindo de forma expressiva para o mapeamento das áreas verticalizadas de Teresina. Carvalho (2015) analisou o processo de verticalização na zona Leste, dando ênfase ao bairro Jóquei, que passou a ser atrativo em decorrência da ação dos agentes produtores do espaço na referida área.

Lima (2011) também contribui com sua pesquisa, a qual objetivou analisar o desenvolvimento de atividade de promoção imobiliária privada em Teresina - PI, onde o mesmo apresenta dados relevantes para pesquisa que segue. No que diz respeito à produção de Frederico Castelo Branco (2012), o mesmo apresenta dados referentes à ação do Estado e do mercado imobiliário no processo de segregação espacial, relevantes para o entendimento da segregação espacial observada na cidade de Teresina.

Rodrigues (2013) propôs, em seu trabalho, analisar o planejamento urbano e as projeções de sua expansão. Apesar de não focar na verticalização, observa-se, neste estudo, que a cidade de Teresina se expandiu consideravelmente em direção às áreas da franja urbana da cidade.

\section{LEIS QUE REGULAMENTAM A VERTICALIZAÇÃO DE TERESINA}

Sabe-se que as leis objetivam regulamentar e disciplinar o homem perante regras, evitando diversos conflitos, sendo que as questões relacionadas ao espaço urbano não são diferentes. Constatou-se que as leis que regulamentam a verticalização na cidade de Teresina referem-se às normatizações de uso e ocupação do solo urbano.

Pode-se afirmar que as questões referentes ao planejamento urbano teresinense influenciam de maneira significativa nas leis existentes na atualidade. Os Planos Estruturais de Teresina e o Plano Diretor de Desenvolvimento Urbano, mesmo não mencionando as construções de múltiplas pavimentações, já indicavam que haveria, posteriormente, a necessidade de regulamentar este tipo de construção na cidade. 
| Verticalização urbana de Teresina-PI: considerações a respeito da produção do espaço a partir da construção vertical|

| Sara Raquel Cardoso Teixeira de Sousa | Bartira Araújo da Silva Viana |

Diversas leis foram e ainda são criadas para regulamentar o uso do solo, a cidade de Teresina possui, na atualidade, cerca de dezessete cadernos contendo leis e códigos que normatizam o uso e ocupação do solo no espaço urbano, sendo que vários artigos e incisos regulamentam construções múltiplas nas diversas regiões da cidade de Teresina. Segundo Teresina (2016), foram analisadas algumas leis em vigência que estão associadas à questão da verticalização indicadas no Quadro 1.

Quadro 1 - Legislações que tratam da questão da verticalização em Teresina - PI

\begin{tabular}{|c|c|}
\hline $\begin{array}{l}\text { LEIS/DECRETOS } / P \\
\text { ORTARIAS }\end{array}$ & DESCRIÇÃO \\
\hline $\begin{array}{l}\text { Lei } N^{\circ} 1.939 \text {, de Agosto } \\
\text { de } 1983\end{array}$ & $\begin{array}{l}\text { Trata do Patrimônio Ambiental, estipula que a frente das construções tenham } \\
\text { medidas de quinze metros laterais, de dois metros e meio e fundo, e um metro } \\
\text { e meio. Fez referência apenas às ruas paralelas a Avenida Frei Serafim, } \\
\text { estabelecendo que o gabarito máximo fosse de quinze metros. }\end{array}$ \\
\hline $\begin{array}{l}\text { Lei } \mathrm{N}^{\circ} 1939 \text {, de } 16 \text { de } \\
\text { Agosto de } 1988\end{array}$ & $\begin{array}{l}\text { No Art. } 5^{\circ}\left(\$ 2^{\mathrm{a}}\right) \text { referia-se aos recuos mínimos, onde a frente que passava a ser } \\
\text { permitida seria cinco metros. As laterais seriam de nove metros e o fundo de } \\
\text { dois metros e meio, com gabarito máximo de quarenta metros. }\end{array}$ \\
\hline $\begin{array}{l}\text { Lei } \mathrm{n}^{\circ} 2.760 \text {, de } 12 \text { de } \\
\text { Abril de } 1990\end{array}$ & $\begin{array}{l}\text { Dá nova redação ao } \int 2^{\circ} \text { do } \text { art }^{\circ} .5^{\circ} \text { da Lei no } 1.939 \text {, de } 16 \text { de Agosto de 1988, } \\
\text { que modifica os recuos das construções. }\end{array}$ \\
\hline $\begin{array}{l}\text { Lei } \mathrm{n}^{\circ} 2.733 \text {, de } 04 \text { de } \\
\text { Dezembro de } 1998\end{array}$ & $\begin{array}{l}\text { Altera a Lei no } 2.265 \text {, de } 16 \text { de Dezembro de 1993, que define as diretrizes para } \\
\text { uso de urbano e dá outras providências. }\end{array}$ \\
\hline $\begin{array}{l}\text { Lei } \mathrm{N}^{\mathrm{o}} 2.760 \text {, de } 12 \text { de } \\
\text { Abril de } 1999\end{array}$ & $\begin{array}{l}\text { Acrescenta uma nova redação, a Lei } \mathrm{N}^{\circ} 1939 \text {, de } 16 \text { de Agosto de } 1988 \text {. No } \\
\text { Art. } 5^{\circ}\left(\$ 2^{\mathrm{a}}\right) \text { referia-se aos recuos mínimos, onde a frente que passava a ser } \\
\text { permitida seria cinco metros. As laterais seriam de nove metros e o fundo de } \\
\text { dois metros e meio, com gabarito máximo de quarenta metros. }\end{array}$ \\
\hline $\begin{array}{l}\text { Lei Complementar de } \\
\mathrm{N}^{\circ} 3.562 \text {, de } 20 \text { de } \\
\text { Outubro de } 2006\end{array}$ & $\begin{array}{l}\text { Refere-se ao uso e ocupação do solo urbano, orienta quanto ao adensamento, à } \\
\text { estruturação e o desempenho das funções urbanas, dentre outros aspectos. No } \\
\text { Capitulo II regulamenta a altura das construções na área de abrangência do } \\
\text { cone de aproximação do aeroporto de acordo com as prescrições fixadas pelo } \\
\text { Ministério da Aeronáutica. }\end{array}$ \\
\hline $\begin{array}{l}\text { Lei } \mathrm{n}^{\mathrm{o}} 3.565 \text {, de } 20 \text { de } \\
\text { Outubro de } 2006 .\end{array}$ & $\begin{array}{l}\text { No Art. } 4^{\circ} \text { são considerados empreendimentos de impacto de vizinhança, } \\
\text { aqueles de uso multifamiliar com área construída privativa superior a } 12.000 \mathrm{~m}^{2} \\
\text { (doze mil metros quadrados); aqueles, de uso não residencial, com área } \\
\text { construída superior a } 5.000 \mathrm{~m}^{2} \text { (cinco mil metros quadrados); aqueles, de uso } \\
\text { misto, com área construída destinada ao uso não residencial superior a } 5.000 \\
\mathrm{~m}^{2} \text { (cinco mil metros quadrados); aqueles de uso residencial multifamiliar que } \\
\text { tenham mais de cento e cinquenta unidades. }\end{array}$ \\
\hline $\begin{array}{l}\text { Portaria } \mathrm{n}^{\circ} 957 / \mathrm{GC} 3 \text {, de } \\
9 \text { de Julho de } 2015\end{array}$ & $\begin{array}{l}\text { Cabe ao Estado a regulamentação e a fiscalização de construções verticais no } \\
\text { entorno dos aeroportos. }\end{array}$ \\
\hline $\begin{array}{l}\text { Lei complementar } \mathrm{n}^{\circ} \\
4.729 \text {, de } 10 \text { de Junho } \\
\text { de } 2015\end{array}$ & $\begin{array}{l}\text { No Art. } 160^{\circ} \text {, tem-se que edificação que tiver mais de } 10 \text { (dez) metros de } \\
\text { deslocamento vertical deve ser servida de elevador. ( }\left(1^{\circ}\right) \text { Os elevadores, } \\
\text { quando obrigatórios, devem ter acesso a todos os pavimentos. }\left(\mathbb{S} 2^{\circ}\right) \text { É } \\
\text { admitido mais um pavimento sem elevador somente nos casos em que este seja } \\
\text { parte integrante de unidades do pavimento imediatamente inferior. }\end{array}$ \\
\hline
\end{tabular}

Analisando as leis aqui apresentadas pode-se observar que diversas normatizações não são cumpridas na sua plenitude no espaço urbano teresinense. Um exemplo observado através dos dados analisados na pesquisa, é que a maioria dos condomínios residenciais de 
| Verticalização urbana de Teresina-PI: considerações a respeito da produção do espaço a partir da construção vertical|

| Sara Raquel Cardoso Teixeira de Sousa | Bartira Araújo da Silva Viana |

alto padrão contém mais de $12.000 \mathrm{~m}^{2}$ (doze mil metros quadrados), divergindo assim da Lei no 3.565 , de 20 de Outubro, Lei de impacto de vizinhança.

Essa mesma lei, que corresponde ao texto de uso e ocupação do solo, diz respeito aos recuos das construções obedecendo ao zoneamento econômico de Teresina. Assim, em algumas áreas da cidade pode-se encontrar prédios que ultrapassam mais de 10 (dez) metros de deslocamento vertical, como a região Leste. Estas construções possuem elevador, e áreas com predominância de prédios com 3 e 4 pavimentos, a exemplo das regiões Sul, Sudeste e Centro-Norte.

Conforme dados obtidos por Teresina (2018), é possível observar condomínios que ultrapassam $20.000 \mathrm{~m}^{2}$ (vinte mil metros quadrados) de área construída, quase o dobro do indicado na lei de impacto de vizinhança. Um prédio que ultrapasse as dimensões permitidas pode implicar em diversos problemas à área do qual o mesmo está inserido, desde problemas ambientais até estruturais. A Figura 2 destaca o condomínio Village Leste, no bairro Vale Quem Tem, localizado na região Leste de Teresina, o qual possui mais de $123.000 \mathrm{~m}^{2}$ (cento e vinte e três mil metros quadrados).

Figura 2 - Imagem de satélite adaptada mostrando o Condomínio Village Leste com área de $123.000 \mathrm{~m}^{2}$,

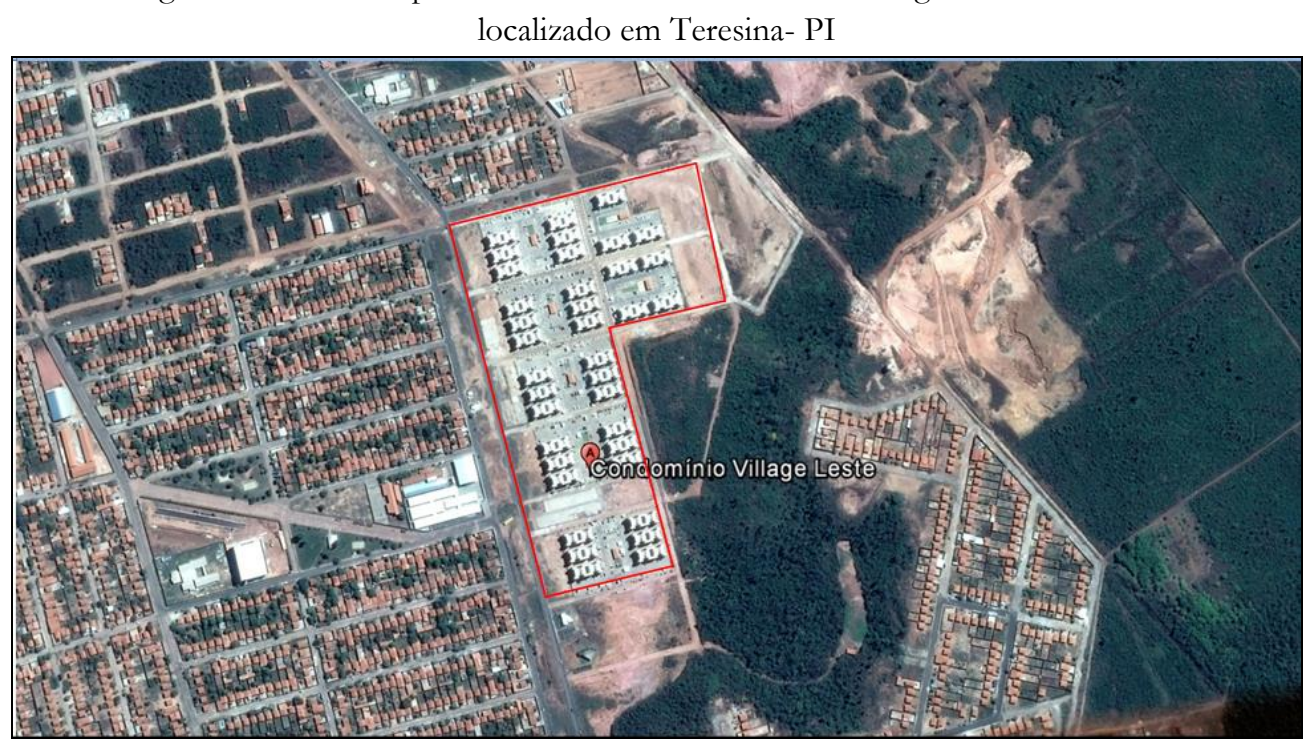

Fonte: Google Earth (2018). Adaptado e Organizado por Sousa (2018).

Apesar de algumas leis não estarem relacionadas exclusivamente a questão da construção de prédios verticais, normatizam, de algum modo, a distribuição dessas edificações nas cidades, a exemplo da Portaria No 957/GC3 da Aeronáutica. Essa portaria influencia na distribuição dos prédios no entorno dos aeroportos das cidades brasileiras. No entanto, no que diz respeito à Teresina, é possível observar prédios com mais de quatro 
| Verticalização urbana de Teresina-PI: considerações a respeito da produção do espaço a partir da construção vertical|

| Sara Raquel Cardoso Teixeira de Sousa | Bartira Araújo da Silva Viana |

pavimentos localizados nas proximidades do Aeroporto Senador Petrônio Portela, de acordo com a Figura 3.

Figura 3 - Imagem de satélite adaptada mostrando os condomínios verticais localizados nas proximidades do

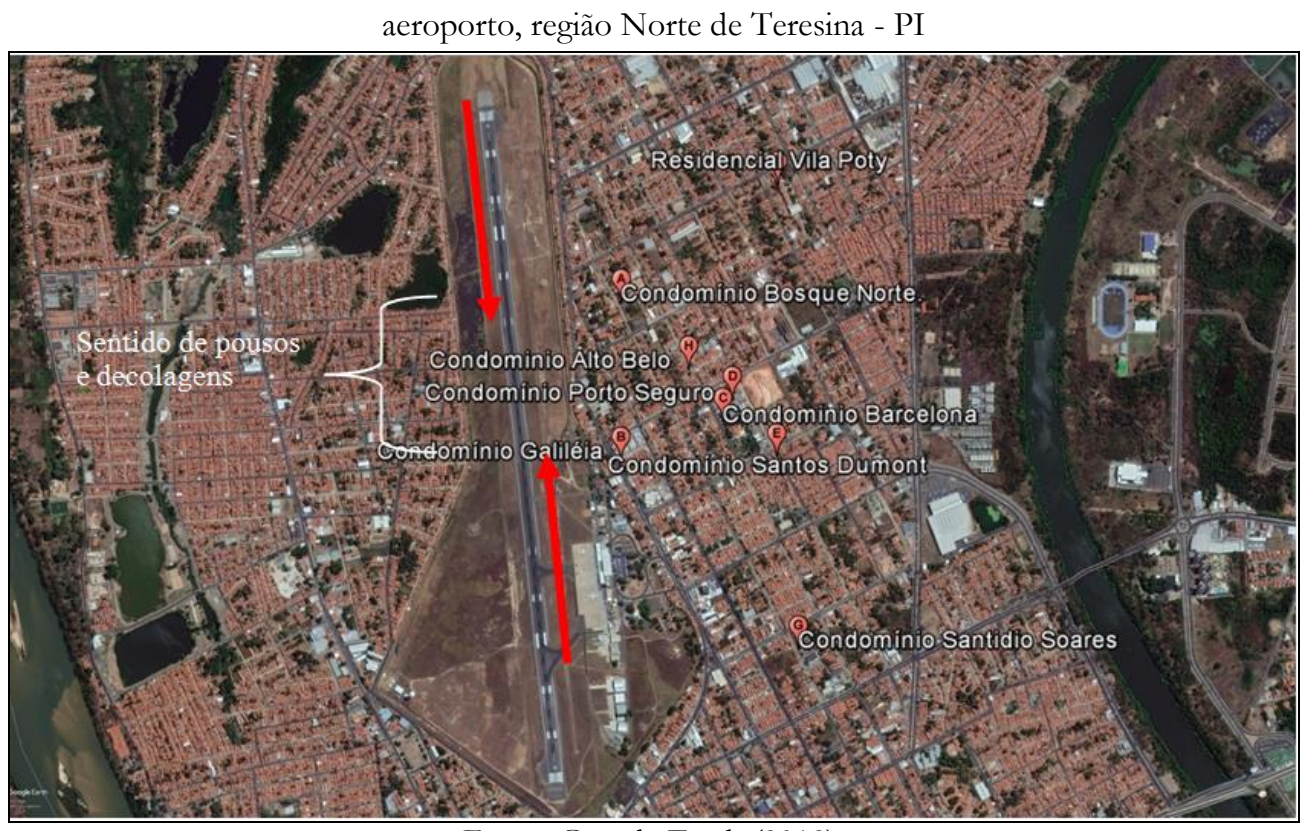

Fonte: Google Earth (2018).

A Lei no 10.098 de 19 de dezembro, a Lei de Acessibilidade, também influencia de forma significativa nas construções verticais. A primeira determinação da mesma é que prédios que contenham ou venham a conter a partir de dois pavimentos tenham elevador. É importante salientar que a mesma lei estabelece que seja obrigatório o uso de elevadores para repartições públicas, no entanto, especifica que não é obrigatório para prédios residenciais.

Levando em consideração a Lei de Acessibilidade, a mesma propõe que os estados e municípios estão livres para desenvolver suas leis próprias, obedecendo às normas da ABNT em vigência que normatizam as construções de modo geral. No que diz respeito à Teresina, não existe uma lei específica que trata da acessibilidade em prédios verticais. Entretanto existem artigos e incisos que normatizam diversas áreas da construção civil e do uso e ocupação do solo influenciando diretamente na construção e reforma de prédios verticais.

Para compreender a expansão da verticalização de Teresina torna-se necessário entender alguns aspectos legais relacionados à gestão territorial urbana. Segundo Teresina (2016), foram criadas as Leis $\mathrm{N}^{\circ} 2.960$ e 2.965, de 26 de Dezembro de 2000, que determinaram fracionamento de Teresina em quatro regiões administrativas gerenciadas por Superintendências de Desenvolvimento Urbano (SDU), a saber: Superintendência do 
| Verticalização urbana de Teresina-PI: considerações a respeito da produção do espaço a partir da construção vertical|

| Sara Raquel Cardoso Teixeira de Sousa | Bartira Araújo da Silva Viana |

desenvolvimento urbano Centro-Norte; Superintendência do desenvolvimento urbano Sul; Superintendência do desenvolvimento urbano Sudeste e Superintendência do desenvolvimento urbano Leste. A finalidade desta regionalização foi aproximar a população dos serviços oferecidos pela Prefeitura Municipal de Teresina.

Ao realizar a pesquisa de campo, observou-se um número significativo de empreendimentos verticais em fase de conclusão e também prédios abandonados. Os primeiros dados obtidos são oriundos da análise de trabalhos do mesmo objeto de estudo. Verificou-se que as produções que versam a respeito do processo de verticalização de Teresina ainda são modestas, levando-se em consideração as demais temáticas geográficas que englobam a cidade. No entanto, foi possível encontrar trabalhos que consideram o tema abordado também em outras ciências, como a Arquitetura e a História.

A maioria dos trabalhos realizados tem como objeto de estudo a região Leste de Teresina. Analisando os dados pesquisados por outros autores, a exemplo Araújo (1992), constatou-se que na década de 1990 diversos empreendimentos imobiliários ainda estariam em fase inicial de construção. Sua pesquisa analisa a verticalização relacionado-a à segregação espacial em Teresina.

Viana (2003) contabilizou os empreendimentos verticais construídos desde os anos de 1970 a 2003. Esta autora mostrou que dos prédios analisados, 75\% concentravam-se apenas nos bairros Jóquei, Centro e Avenida Frei Serafim. Os demais 25\% estariam concentrados nos bairros Fátima, Ilhotas, Noivos, Cabral e Ininga.

Baseados nos dados de Viana (2003) ainda é possível informar que foi possível contabilizar 97 edifícios construídos entre 1970 e 2003, sendo importante observar a evolução também do número de pavimentos ao longo dos anos. A década de 1990 contabilizou o maior número de empreendimentos, sendo que os mesmos possuíam entre 3 e 24 pavimentos (Quadro 2), evidenciando uma tendência de crescimento. Cumpre destacar que a autora obteve seus dados através das imobiliárias, pesquisas de campo e através de dados coletados na Prefeitura Municipal de Teresina. De acordo com Teresina (2010), até o ano de 2009 foram contabilizados 183 empreendimentos verticais, a partir de quatro pavimentos. 
| Verticalização urbana de Teresina-PI: considerações a respeito da produção do espaço a partir da construção vertical|

| Sara Raquel Cardoso Teixeira de Sousa | Bartira Araújo da Silva Viana |

Quadro 2 - Empreendimentos verticais construídos em Teresina (PI) desde os anos de 1970 a 2003.

\begin{tabular}{|c|l|}
\hline Década & \multicolumn{1}{c|}{ Número de empreendimentos verticais } \\
\hline 1970 & Foram construídos 3 edifícios que possuíam entre 3 e 6 pavimentos \\
\hline 1980 & Foram construídos 26 edifícios que possuíam entre 3 e 13 pavimentos \\
\hline 1990 & Foram construídos 59 edifícios que possuíam entre 3 e 24 pavimentos \\
\hline 2000 a 2003 & Foram construídos 9 edifícios que possuíam entre 3 e 15 pavimentos \\
\hline
\end{tabular}

Fonte: Adaptado de Viana (2003).

$\mathrm{Na}$ pesquisa de campo (visita técnica aos órgãos públicos), foram disponibilizados dados mais recentes mostrando a evolução no número de construções verticais em Teresina empreendidos até o ano de 2017, e foram contabilizados 727 edificações verticais, havendo maior concentração na região Leste de Teresina (Gráfico 1). É importante destacar que este número diz respeito a prédios públicos e privados, independente do número de torres. No entanto, no mapeamento apresentado neste estudo, foram incluídas todas as torres contidas nos condomínios residências, sendo que a maioria das destas edificações recentes construídas em Teresina possuem diversas torres de apartamentos.

Gráfico 1 - Número de prédios construídos a partir de 4 pavimentos.

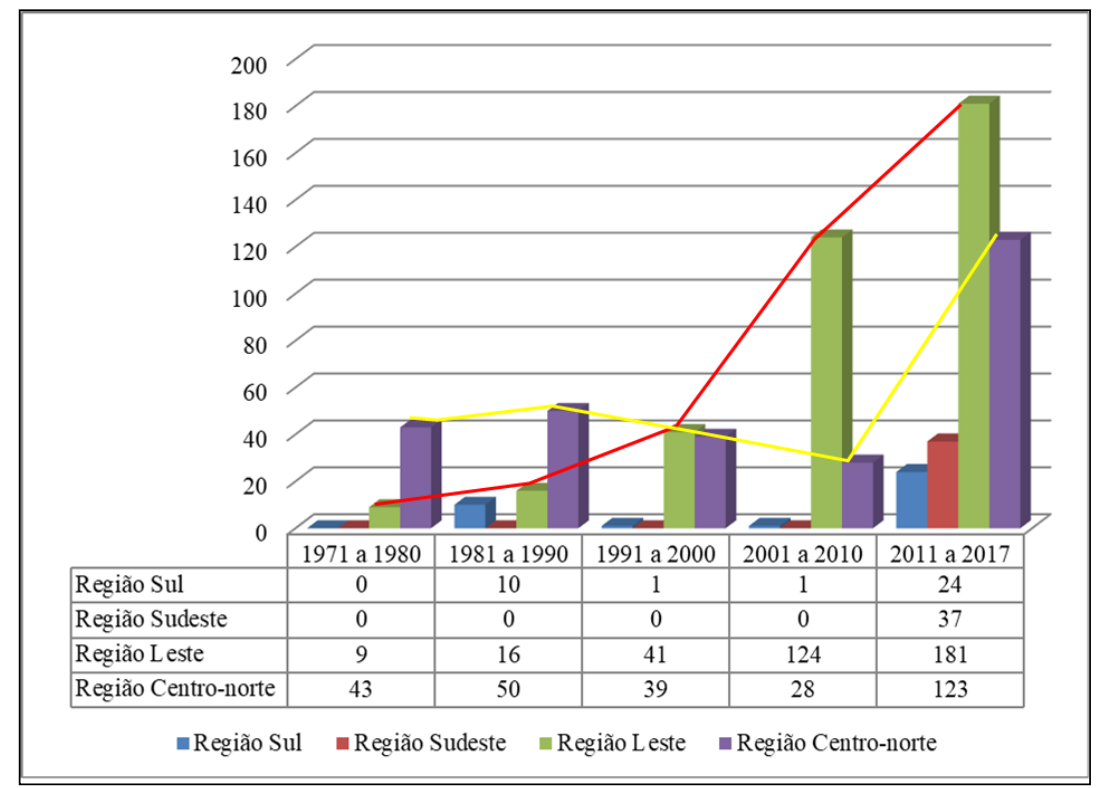

Nas linhas em amarelo e vermelho, a linha de variação de construção dessas unidades nas regiões CentroNorte e Leste, respectivamente. Fonte: Pesquisa direta (2018).

De posse desses dados, houve a necessidade de realizar outra visita de campo com o objetivo de reconhecer a área e coletar os primeiros dados. Essa pesquisa foi necessária, pois foi observado, através da apuração dos dados, uma disparidade dos seguintes dados: no número de prédios (dados tabelados) x número de prédios (reais); no número de 
| Verticalização urbana de Teresina-PI: considerações a respeito da produção do espaço a partir da construção vertical|

| Sara Raquel Cardoso Teixeira de Sousa | Bartira Araújo da Silva Viana |

prédios a partir de quatro pavimentos; prédios em construção; prédios abandonados; endereços distintos do mesmo condomínio.

Ao compararmos os dados disponibilizados pela Prefeitura de Teresina correspondente aos anos de 2000, 2010, 2013, 2016 e 2018, observou-se que o número total de prédios divergia, quando comparados os mesmos períodos, nas diversas tabelas, e em algumas inexistiam os dados dos prédios construídos na década de 1970. Alguns prédios construídos até 1990, pagantes de Imposto sobre a propriedade Predial e Territorial Urbana, não apareceram nas tabelas de 2010 até 2017, ao contrário de outros que multiplicaram o número de unidades pagantes de IPTU.

A visita de campo permitiu observar também que os prédios abandonados (Figura 4) em sua maioria estão localizados na região Leste de Teresina. Segundo a Revista Cidade Verde (2016), as obras abandonadas são notificadas pela Superintendência de Desenvolvimento Urbano da área onde o prédio encontra-se construído, levando em consideração que o abandono e a falta de manutenção colaboram para a proliferação de doenças tropicais, como a Dengue. Esta situação também contribuiu para o estabelecimento de infrações referentes ao Código de Postura do Município de Teresina, visto que estes prédios são de responsabilidade das empresas ou construtoras cujo registro consta na Prefeitura Municipal de Teresina.

Figura 4 - Fotografias em mosaico mostrando os prédios abandonados em Teresina - PI

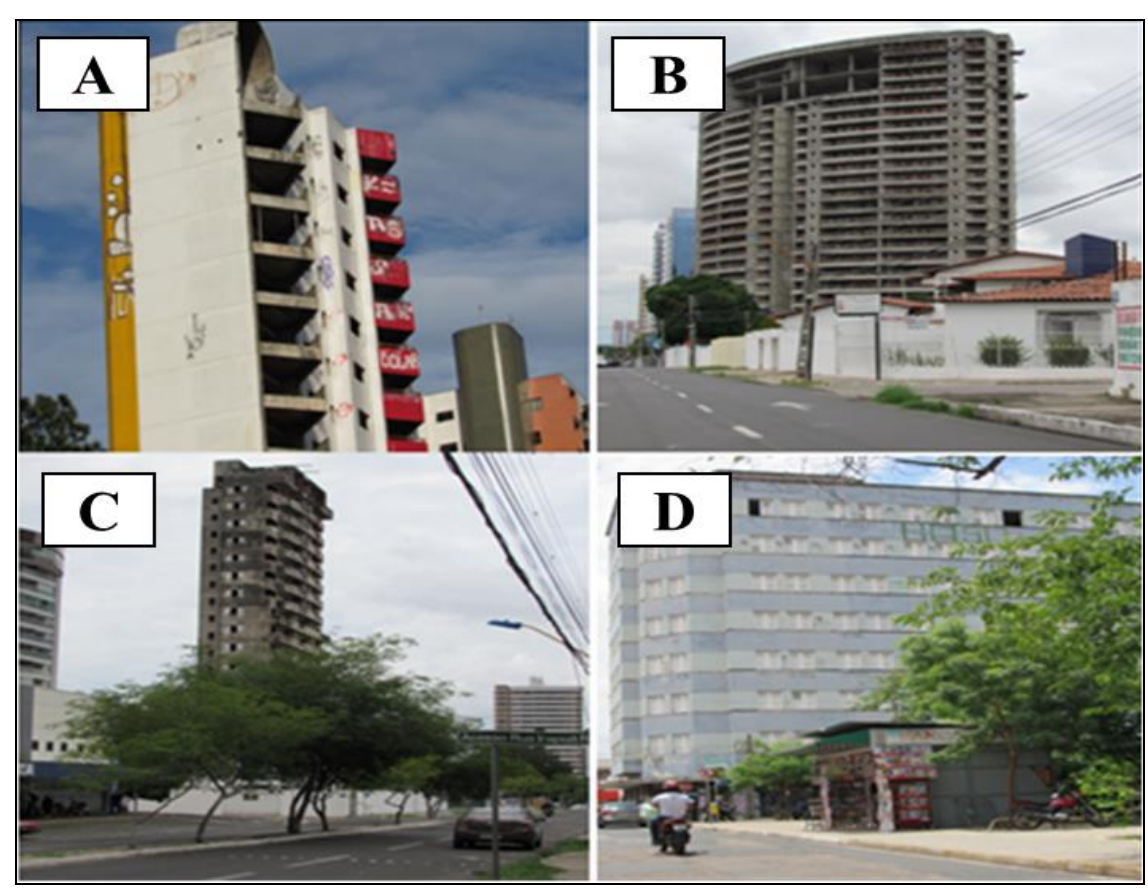

A/B/C: Prédios abandonados, porém não concluídos; D: Prédio abandonado, porém foi concluído e funcionou durante muitos anos.

Fonte: Sousa (2018). 
| Verticalização urbana de Teresina-PI: considerações a respeito da produção do espaço a partir da construção vertical|

| Sara Raquel Cardoso Teixeira de Sousa | Bartira Araújo da Silva Viana |

Sabóia (2016, p. 35) publicou dados em uma matéria jornalística que apontam alguns dos problemas ocasionados pelo abandono de prédios. Segundo este autor:

\begin{abstract}
Muitas construções que deveriam se tornar edifícios de apartamentos de alto padrão, encontram-se hoje apenas acumulando sujeira e servindo de esconderijo para marginais. Esses prédios podem ser vistos em algumas das avenidas mais valorizadas de Teresina, como Dom Severino e Elias João Tajra.
\end{abstract}

O mesmo autor em sua reportagem mostra dados relevantes sobre o abandono de empreendimentos na cidade de Teresina que englobam os prédios verticais, objeto da pesquisa em curso. De acordo com a Revista Cidade Verde $(2016)^{1}$, foram notificadas até o ano de 2016 seis construções verticais abandonadas apenas na região Leste de Teresina.

No que diz respeito à região Centro-Norte, uma edificação vertical abandonada destaca-se na paisagem. Segundo o Jornal Diário do Povo (2001), um prédio bastante conhecido por ter sediado o Instituto Nacional de Seguro Social (INSS) até o ano de 1993 em Teresina, localizado no cruzamento da rua David Caldas e Coelho Rodrigues, Bairro Centro. Este edifício foi evacuado depois de um forte tremor de terra registrado no ano de 1993, e teve que ser evacuado às pressas.

Constatou-se que estudos científicos que versam sobre a temática do abandono de prédios são raros, sejam eles verticais ou horizontais e, assim, as discussões ficam restritas a alguns poucos artigos de jornais impressos e portais online. Nas matérias analisadas, destaca-se o estudo de Viana (2013), considerada referência no que diz respeito aos dados geográficos sobre verticalização de Teresina. No entanto, pouco se discute acerca de prédios abandonados.

No que diz respeito à analise documental de jornais locais, contatou-se ainda que há dificuldades em encontrar em órgãos públicos informações a respeito dos prédios abandonados, pois as informações apresentadas, em sua maioria, são relatos dos superintendentes das Superintendência de Desenvolvimento Urbano e dados apresentados por entrevistas com presidentes de sindicatos ligados a construção civil.

\title{
CONCLUSÃO
}

\footnotetext{
1 Tendo em vista que durante o desenvolvimento da pesquisa não foram disponibilizadas, por parte dos órgãos públicos municipais, documentos que fazem referência às construções abandonadas em Teresina, fezse necessário analisar uma série de matérias jornalísticas que contemplam o tema dos prédios abandonados no município de Teresina.
} 
| Verticalização urbana de Teresina-PI: considerações a respeito da produção do espaço a partir da construção vertical|

| Sara Raquel Cardoso Teixeira de Sousa | Bartira Araújo da Silva Viana |

Através do estudo foi possível constatar que, apesar de urbanizar-se tardiamente, comparado com outras cidades brasileiras, a capital do Piauí demonstra, ao longo de sua história, um padrão de verticalização que acompanha as mudanças econômicas ocorridas no país e sofreu influências externas importantes que determinaram a verticalização de áreas específicas da cidade.

A pesquisa de campo tornou-se necessária para a obtenção e interpretação de dados estatísticos disponibilizados pela Prefeitura Municipal de Teresina e foi um importante instrumento que permitiu a obtenção e apreciação de dados não revelados através dos relatórios analisados, como a função dos prédios construídos, a espacialização dos mesmos, assim como a quantidade.

Constatou-se na pesquisa que, por volta da década de 1970, as edificações verticais comerciais começam a ocorrer no centro da cidade de Teresina. A produção de empreendimentos verticais residenciais se intensifica na década de 1980 e se consolida na década de 1990 nas regiões Centro-Norte e Leste, devido a investimentos em infraestrutura e serviços, agregando valor inicialmente às áreas de alguns bairros, como Cabral e Ilhotas (região Centro-Norte), Jóquei e Fátima (região Leste) e avenida de Frei Serafim.

Nos anos 2000 e 2010, a região Leste continua sendo a mais atrativa para construção de empreendimentos verticais de padrão elevado, refletindo o grande dinamismo do setor imobiliário e o papel do Estado como responsáveis pela (re) estruturação do espaço urbano.

Porém, as regiões Sul, Sudeste e Centro-Norte têm se configurado como novas áreas de atuação destes agentes produtores do espaço, a partir de investimentos que visam atender uma parcela da população de menor poder aquisitivo. Assim, o crescimento das áreas verticais acompanha a expansão da área urbana de Teresina e o padrão de verticalização das distintas regiões administrativas se diferencia conforme o valor da terra.

Outro fato importante a destacar diz respeito à legislação. Os artigos e incisos que referenciam as questões que envolvem o crescimento vertical fazem parte de leis de uso e ocupação do solo urbano, não havendo leis específicas que tratam da verticalização da cidade estudada.

Concluiu-se que a tendência de expansão da verticalização da cidade de Teresina seguiu o sentido da franja urbana, ocorrendo um crescimento significativo de novas áreas verticais afastadas das regiões onde a verticalização encontra-se consolidada. As regiões Leste e Centro-Norte possuem o maior número de construções verticais da cidade de Teresina. 
| Verticalização urbana de Teresina-PI: considerações a respeito da produção do espaço a partir da construção vertical|

| Sara Raquel Cardoso Teixeira de Sousa | Bartira Araújo da Silva Viana |

\section{REFERÊNCIAS}

ABREU, Irlane Gonçalves de. Geografia urbana: questões sobre sua natureza e seu objeto. In: CARLOS, Ana Fani Alessandri (Org.). Os Caminhos de reflexão sobre a cidade e o Urbano. São Paulo: Edusp, 1994. p. 129-135.

ABREU, Irlane Gonçalves de. $\mathbf{O}$ crescimento zona leste de Teresina: um caso se segregação? 1983. 136 f. Dissertação (Mestrado em Geografia) - Universidade Federal do Rio de Janeiro, Rio de Janeiro, 1983.

AFFONSO, Carlos Antônio Alves. Planejamento estratégico e o Plano Agenda 2015. Scientia et Spes, ICF, Teresina, ano 1, n. 2, p. 71-92, 2002.

CARLOS, Ana Fani Alessandri. A reprodução do espaço urbano como momento da acumulação capitalista. In: CARLOS, Ana Fani (Org.). Crise urbana. São Paulo: Contexto, 2015.

A condição espacial. São Paulo: Contexto, 2011.

O lugar no/do mundo. São Paulo: Labur, 2007.

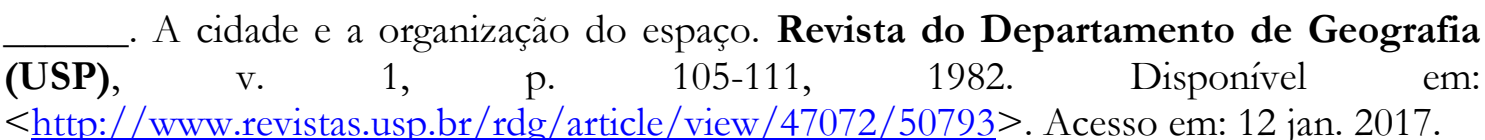

CORRÊAA, Roberto Lobato. Sobre agentes sociais, escala e produção do espaço: um texto para discussão. In: CARLOS, Ana Fani; SOUZA, Marcelo Lopes de; SPOSITO, Maria Encarnação (Org.). A produção do espaço urbano: agentes e processos, escalas e desafios. São Paulo: Contexto, 2013. p. 41-51.

Segregação residencial: classes sociais e espaço urbano. In: VASCONCELOS, Pedro de Almeida; CORREAA, Roberto Lobato; PINTAUDI, Silvana Maria (Org.). A cidade contemporânea: segregação espacial. São Paulo: Contexto, 2013. p. 39-59.

CORREAA, Roberto Lobato. Trajetórias Geográficas. 2. ed. Rio de Janeiro: Bertrand Brasil, 2002.

O espaço urbano. São Paulo: Ática, 1989.

COSTA, Wandemara de Oliveira; VIEIRA, Nadja Rodrigues Carneiro; VIANA, Bartira Araújo da Silva. Diagnóstico da ação dos agentes produtores do processo de verticalização em Teresina-PI nos últimos quarenta anos a partir da análise de documentos eletrônicos e materiais de publicidade. Revista Equador (UFPI), Teresina, v. 5, n. 3 (Edição Especial 02), p. 220-238, ago. 2016.

FAÇANHA, Antonio Cardoso. Uma nova Geografia da cidade de Teresina. Jornal Meio Norte, Teresina, 16 ago. 2009.

A evolução urbana de Teresina; passado, presente e...Carta CEPRO, Teresina, v. 22, n. 1, p. 59-69, jan./jun. 2003. 
| Verticalização urbana de Teresina-PI: considerações a respeito da produção do espaço a partir da construção vertical|

| Sara Raquel Cardoso Teixeira de Sousa | Bartira Araújo da Silva Viana |

A evolução urbana de Teresina: agentes, processos e formas espaciais. 1998. 234f. Dissertação (Mestrado em Geografia) - Universidade Federal de Pernambuco, Recife, 1998.

FREITAS, Ruskin Marinho de. Entre mitos e limites: as possibilidades do adensamento construtivo face à qualidade de vida no ambiente urbano. Porto Alegre: UFRGS, Faculdade de Arquitetura, 2005.

GOTTSCHALG, Maria de Fátima S. Segregação sócio-espacial urbana e intervenção estatal: uma abordagem geográfico-social: Documento Especial. Minas Gerais: CRESS, 2012. Disponível em: < http://www.cress-mg.org.br/arquivos/DE\%203.pdf $>$. Acesso em: 10 jan. 2017.

OLIVEIRA, Paulo Victor Hipolito de; OLIVEIRA, Pedro Henrique Hipolito de; MENDES, Wander Luis de Faria; OLIVEIRA, Muriel Batista de; SORAGGI, Marcus Vinicius. A verticalização consciente: edificar integrando ao meio urbano. REINPEC, Rio de Janeiro, v. 1, n. 2, p. 13-29, jan./jun. 2015.

RODRIGUES, Marcely Pereira da Silveira. A natureza da verticalização no processo de reprodução do espaço urbano em Palmas-TO. 2016. 118 f. Dissertação (Mestrado em Geografia) - Universidade Federal de Tocantins, Porto Nacional, 2016.

SANTOS, Milton. Metamorfose do espaço habitado: fundamentos teóricos. 6. ed. São Paulo: Editora da Universidade de São Paulo, 2008.

SILVA, Ângela Martins Napoleão Braz e. O Plano de implantação da cidade de Teresina (1852). Cadernos PPG-AU, Universidade Federal da Bahia, Salvador, ano 7, Número Especial, p. 43-45, 2008. Disponível em: <http://arquiteturaurbanaufpi.blogspot.com.br/2011 0101 archive.html>. Acesso em: 19 nov. 2016.

Planejamento e fundação da primeira cidade no Brasil Império. PROARQ 18, Universidade Federal do Rio de Janeiro, Rio de Janeiro, ed.18. p. 215-236, 2012. Disponível em:

$<$ http://www.proarq.fau.ufrj.br/revista/public/docs/Proarq18 Planejamento AngelaSilva .pdf>. Acesso em: 20 nov. 2016.

SILVA, José Borzacchiello da. Discutindo a cidade. In: ; COSTA, Maria Clélia. Lustosa; DANTAS, Eustógio Wanderley C. (Org.). A cidade e o urbano: temas para debates. Fortaleza: EUFC, 1997.

SOUZA, Marcelo Lopes de. ABC do desenvolvimento urbano. 4. ed. Rio de Janeiro: Bertrand Brasil, 2008.

SOUZA, Maria Adélia A. A Identidade da Metrópole. São Paulo: EDUSP, 1994.

SPOSITO, Maria Encarnação B. O chão arranha o céu: a lógica da (re)produção monopolista da cidade. 1991. 394 f. Tese (Doutorado em Geografia) - Universidade de São Paulo, São Paulo, 1991.

A produção do espaço urbano: escalas, diferenças e desigualdades socioespaciais. In: CARLOS, Ana Fani; SOUZA, Marcelo Lopes de; SPOSITO, Maria Encarnação (Org.). 
| Verticalização urbana de Teresina-PI: considerações a respeito da produção do espaço a partir da construção vertical|

| Sara Raquel Cardoso Teixeira de Sousa | Bartira Araújo da Silva Viana |

A produção do espaço urbano: agentes e processos, escalas e desafios. São Paulo: Contexto, 2013.

TERESINA, Prefeitura Municipal de. Imagens antigas. Teresina: Secretaria Municipal de Planejamento; PMT, 2016. Disponível em: < http://semplan.teresina.pi.gov.br/>. Acesso em: 13 jan. 2017.

Secretaria Municipal de Finanças. Coordenação Especial da Receita do Município. Gerência Executiva de IPTU. Relatório de condomínios verticais com número de pavimentos superior a três. Cadastro imobiliário fiscal. Teresina: PMT, 2018.

Secretaria Municipal de Finanças. Coordenação Especial da Receita do Município. Gerência Executiva de IPTU. Relatório de condomínios verticais com número de pavimentos superior a três. Cadastro imobiliário fiscal. Teresina: PMT, 2013.

. Secretaria Municipal de Finanças. Coordenação Especial da Receita do Município. Gerência Executiva de IPTU. Relatório de condomínios verticais com número de pavimentos superior a três. Cadastro imobiliário fiscal. Teresina: PMT, 2016.

Secretaria Municipal de Finanças. Coordenação Especial da Receita do Município. Gerência Executiva de IPTU. Relatório de condomínios verticais com número de pavimentos superior a três. Cadastro imobiliário fiscal. Teresina: PMT, 2010.

2016.

Lei $\mathrm{n}^{\mathrm{o}} 3.565 / 2006$. Uso do Solo, Diário Oficial do Município de Teresina,

Lei $\mathrm{n}^{\circ} 5.562$ de 20 de outubro de 2006. Diretrizes de Uso e Ocupação do Solo Urbano, Diário Oficial do Município de Teresina, Teresina, PI, 2006.

Lei Complementar No 1932 de outubro de 1988. Dispõe sobre a instituição do II Plano Estrutural de Teresina e dá outras providências. Diário Oficial do Município de Teresina, Teresina, PI, 1998.

Lei No 1.939 de Agosto de 1983. Uso e Ocupação do Solo Urbano. Diário Oficial do Município de Teresina, Teresina, PI, 1983.

VIANA, Bartira Araújo da Silva. A verticalização de Teresina: sonho de muitos e realidade de poucos. 2003. 134 f. Trabalho de Conclusão de Curso (Especialização em Geografia) - Universidade Federal do Piauí, Teresina, 2003.

Segregação de alto status. Jornal Diário do Povo, Teresina - Piauí, jul. 2001.

A verticalização de "alto status" em Teresina. Revista Mercado imobiliário, Teresina-PI, 2007. 